\title{
PAID LEAVE POLICIES AND PARENTAL LEAVE CHOICES IN LITHUANIA
}

\author{
Rūta Brazienè, Sonata Vyšniauskienè \\ Vilnius University, Lithuanian Social Research Centre
}

\begin{abstract}
This paper focuses on paid leave policies and parents parental leave choices in Lithuania. Lithuanian paid parental leave system provides one of the longest leaves in Europe, with high replacement rates, but there is a lack of more flexible working arrangements for working parents. For an empirical analysis an administrative data of SODRA (State Social Insurance Fund Board), which includes information of all benefits recipients was used. SODRA data allowed to disclose the gender differences in the parent's parental leave choices by gender (2011-2018). This period has been chosen because Lithuania in 2011 introduced new paid leave policy regulation, when two parental leave options were offered for parents: $100 \%$ of net earnings until the child is 12 months or $70 \%$ of net earnings until the child is 12 months, and $40 \%$ net earnings until the child is 24 months. The SODRA data had shown that although the share of fathers who take paid parental leave had increased since 2011 but in comparison to women it constituted only about $24 \%$ of all $\mathrm{f}$ paid parental benefits recipients. Considerably larger part of the fathers is choosing to receive the parental leave benefits the second year while they are eligible to work and benefit is not reduced.

KEY WORDS: paid parental leave schemes, paid parental leave choices among parents, gender differences.
\end{abstract}

\begin{abstract}
Anotacija
Straipsnyje pateikta mokamos vaiko priežiūros sistemos Lietuvoje ir tėvų vaiko priežiūros atostogų pasirinkimo analizè. Mokama vaiko priežiūros atostogu sistema Lietuvoje pasižymi ilga trukme, didelèmis išmokomis, vis dèlto lankstesnių darbo organizavimo formų tėvams trūksta. Atliekant empirinę analizę remtasi „Sodros“ (Valstybinio socialinio draudimo fondo valdybos) administraciniais duomenimis, ị kuriuos įtraukta informacija apie visus išmokų gavejus. „Sodros“ duomenys leido atskleisti mokamų vaiko priežiūros atostogų pasirinkimą lyties aspektu (2011-2018). Šis laikotarpis pasirinktas, nes $2011 \mathrm{~m}$. nustatytas naujas mokamų vaiko priežiūros atostogų reguliavimas, kai tèvai galëjo rinktis iš dviejų mokamų vaiko priežiūros atostogų galimybių: $100 \%$ buvusių pajamų, kol vaikui sueis 12 mėnesių, $70 \%$ buvusių pajamų, kol vaikui sueis 12 mėnesių, ir $40 \%$ buvusių pajamų, kol vaikui sueis 24 mènesiai. „Sodros“ duomenys atskleide, nors teečų, kurie pasiima mokamas vaiko priežiūros atostogas, skaičius nuo 2011 m. nuolat augo, lyginant su moterimis, vyrų, išeinančių mokamų vaiko priežiūros atostogų, dalis sudaro tik apie $24 \%$ visų mokamų vaiko priežiūros išmokų gavejjų. Gerokai didesnè dalis teč̌ių renkasi mokamas vaiko priežiūros atostogas antraisiais metais, kai jie gali dirbti ir gaunama išmoka nemažinama.

PAGRINDINIAI ŽODŽIAI: mokamų vaiko priežiūros atostogų schema, vaiko priežiūros atostogų pasirinkimai, lyčių skirtumai.
\end{abstract}

DOI: http://dx.doi.org/10.15181/tbb.v85i2.2189 


\section{Introduction}

The processes of socio-economic transformation, Lithuania's membership in the European Union and EU integration (gender equality questions, meaning equal opportunities for men and women to participate in the labour market the major changes that led to a scientific debate and research on family-friendly policies, paid parental leave, reconciliation of work and family roles. In addition, another important aspect to be mentioned, i.e. demographic situation in Lithuania, declining birth rate and the fact that the formation of work and family roles, and familyfriendly environment is likely to be a measure of promoting birth rates. Furthermore, at European Union level, promoting women's participation in the labour market is one of the objectives of the Europe 2020 strategy, e.g. to reach $75 \%$ of women between the ages 20 and 64 would participate in the labour market.

There is quite generous maternity, paternity and paid parental leave benefits schemes based on employment and previous salary in Lithuania. Generally, parents (mostly women) take long parental leaves in Lithuania. The parents can take parental leave until the child is three years old, but the period after the child is 24 months old is unpaid. Therefore, the majority of the parents are taking parental leave until the child is two years old. The largest part of the children starts to attend childcare institutions at the age of two. According to Lithuanian Statistics in 2018, kindergartens and pre-school education groups in general were attended by $29.8 \%$ of $0-3$ years old children and aged 1-6 years attended kindergartens and pre-school education groups at $74.2 \%$. One of the aims of paid parental leave is to promote gender equality and women's employment in the labour market. While women's employment in Europe and Lithuania has increased significantly in recent decades, we can debate whether women's potential is fully exploited in the labour market. Modification of the traditional gender division of work is promoted through socalled work-life balance policies, including paid parental leave, access to childcare education, family-friendly work organization forms and mechanisms to promote a balanced distribution of unpaid work between men and women.

Family-friendly policies are one of the key tools for ensuring that parents can reconcile parental care and labour market participation. Despite the fact that researchers and social policy practitioners have been debating this topic extensively over the past decade, the smooth reconciliation of family and professional life remains a main issue. EU countries deal with these issues differently, depending on family-friendly policies (paid parental leave, availability of childcare education, flexible working time arrangements, etc.). The analysis of paid parental leave systems first reveals, where we can observe a considerable diversity between different family and labour market policies, the extent to which work / professional and pa- 
rental leave sharing between parents is encouraged in different countries. In many countries, particularly in Europe, family-friendly policies aim to ensure gender equality in the labour market and to involve men as much as possible in the care responsibilities (Almqvist, Duvander, 2014; Ferrarini, Duvander, 2010).

There is a number of the studies aimed at analysis of family-friendly policies, different aspects of paid parental leave (length, conditions, etc.). Duvander, Viklund (2019) analysed methodological and policy dimensions of parental leave length. Evertson, Duvander (2011) measured Swedish women's labour market opportunities for upward occupational moves; Duvander, Ellingsæter (2016) evaluated cash for care system analysis in the Nordic countries, stating that long period of childcare may limit women's future labour market integration. Ferrarini, Duvander (2010) examined how parental leave in general affects parental participation and gender equality. Vallarino et al. (2018), in their studies came to conclusions that leave policy preferences are mostly influenced by the institutional and cultural context, also stating that leave policy preferences roughly reflect the current leave scheme in each country and this requires further research. Šarlauskas and Telešienè (2014) in their study concluded that Lithuanian state social insurance parental allowance system and choices of beneficiaries showed clear policy tendencies to move forward to a more male breadwinner model. With the emphasis on long periods of absence from work and relatively small compensations, parental leave policy devalues family care in relation to employment and does not provide choices for women to (re-)move from family care to employment. Since 2014 a yearly country note on leave policies developments has been prepared for Lithuania (Braziene, 2020; 2019; 2018; 2017; etc.). In recent years, in Lithuania, many studies considered family-friendly policies and more demographic perspective of family formations, work-life balance conflict, fertility rates, cohabitation, families and inequalities etc. (Maslauskaite, Stankuniene, 2003; 2004; 2006; 2012; Aidukaite, 2006). Paid leave policies and parents choices are clearly lacks more comprehensive analysis. The main research question is as follows: what are the paid parental leave choices of Lithuanian parents?

\section{Theoretical background}

Traditional vs. modern gender roles. For men and women gender remains a primary frame defining who they are, how they behave or will behave, and how they expect other sex to behave. Knowledge drawn on cultural "common" and "everybody knows", to coordinate their behaviour and facilitate social cohesion (Ridgeway, 2011, p. 35). This knowledge brings along cultural stereotypes about how men and women behave and emphasizes the perceived differences between the two groups. 


\section{PAID LEAVE POLICIES AND PARENTAL LEAVE CHOICES IN LITHUANIA}

Gender role ideology influences the links between the division of labour, perceived fairness or marital quality in a number of ways. Division of labour itself is dependent on the gender role orientation of the spouses. The stronger traditional gender roles couple endorse the more uneven participation of women and men in household tasks (Greenstein, 1996; Shelton, John, 1996; Thompson, Walker, 1989). Existing research across Europe has indicated that on the individual level, parents' negotiations regarding their work-care arrangements are shaped by cultural norms and gender ideologies that share a common base: both partners usually consider childcare a mother's main responsibility, which means that her employment is adjusted to this responsibility and her income is surplus or 'extra' money (Lammi-Taskula, 2007). To ad, gender role ideology shapes the perception of fairness or injustice of the division of labour. According to the study (Walker, Thompson, 1989) women do not grasp gendered division of housework as "not fair" if 1) corresponds to what they are socialized to value in a relationship (outcome values), 2) matches their social and normative standards, 3) is perceived as justifiable or legitimate. In addition, various cultural groups attach different symbolic meanings for housework, which reflect in the perception of fairness (John, Shelton, Luschen, 1995). The number of studies found that the perception of unfairness affects reported marital quality more strongly for egalitarian wives than for traditional wives (Greenstein, 1996; Kluwer, Heesink, Van de Vliert, 1997).

Social and cultural norms towards gender roles have shown to have a large effect on economic outcomes of men and women. Unequal division of care is one of the causes behind gender inequalities (penalty of motherhood) (Gornick, Meyers, 2004). (On one hand, leave policies increase female labour market participation. On the other hand, long career breaks generate inequalities since men do not share the leave equally and the leave-taking becomes gendered. (Gornick, Meyers, 2004) Established traditions, patriarchal attitudes, gender stereotypes etc. are possible explanations for this phenomenon, Castells (2003) argues, "Patriarchalism is the main structure of all contemporary societies. For its characteristic, institutionally established men power to women and children in the family. If this power would be effective, patriarchalism would pervade all organization of society - from production to consumption and policy, law and culture". Morgan emphasizes that in most contemporary societies, hegemonic masculinity strongly relates to paid work (Morgan, 1992). Merla (2008) points out that there is a tension between assigned norms and personal identity of fathers, who stay at home and are responsible for childcare. The prevalence of breadwinner ideology is still present, influencing the expectations and the identity of men and fathers (Pfau-Effinger, 2004). In addition, the general perceptions from society for men and fathers are 
very important. Fathers are more likely to participate in childcare with mothers or relatives support (Hoffman, Moon, 1999).

Gøsta Esping-Andersen (1999, p. 51) argues that familialistic and defamiliarizing welfare states can be distinguished: He describes a familialistic system as a system in which households must carry the principal responsibility for their members' welfare. The defamiliarizing regime is understood as a regime, in which one seeks to unburden the household and diminish individuals' welfare dependence on kinship. Family policies comprise different measures that have different impacts on parent's labour market participation, leave policy choices etc. Thevenon and Solaz 2013 identifies six main goals of family policies being: 1) poverty reduction and income maintenance, 2) direct compensation for the economic cost of children, 3) fostering employment, 4) improving gender equality, 5) support for early childhood development, and 6) raising birth rates. The Family Policy Concept (2008) in Lithuania prevails traditional attitudes towards family and gender roles. However, women's possibilities in the labour market are ensured by gender equality legislation, e.g. the Law on Equal Opportunities for Women and Men (1998) and the Law for Equal Treatment (2005). In one of the more recent strategic documents the Action Plan of Comprehensive Provision of Services for Families 2016-2020 (approved in 2016), among the services provided for families, point 22.2 in the Action Plan states the intention to expand access to quality childcare services and improve reconciliation of family and work roles.

Human development has led to a change in cultural attitudes towards gender equality, various forms of modernization related to economic development and globalization. Modernization is taking over, changes in gender roles: First, industrialization has forced women into paid jobs and drastically reduced birth rates. Women gain literacy and education opportunities. Likewise, women are beginning to participate in representative government, but to this day, they have less power than men do. Similarly, the post-industrial phase has fundamentally changed gender equality as women grow in leadership or gain political influence in elected and appointed bodies (Inglehart, Norris, 2003). Cultural change in modern society is not enough to guarantee women's equality in all key aspects of life; nevertheless, they greatly facilitate the process by supporting structural reforms and women's rights (Inglehart, Norris, 2003).

The presence of children plays an important role for parents (especially mothers) labour market participation. The employment rate of women with children aged less than six years old is at $74.6 \%$ - this is above the EU average of $62.4 \%$. The employment rate of men with children aged less than six years old is at $89.6 \%$ - this is similar to the EU average of $89 \%$. The trends of female and male employment in Lithuania are similar: the female employment rate has increased 
over the past ten years, while the male employment rate has also increased. Moreover, the employment rate of adults with children in Lithuania increased from $73.5 \%$ in 2010 to $83.9 \%$ in 2017 , following the EU-28 rate which increased from $75 \%$ in 2010 to $77.9 \%$. The number of children is also an important factor for parent's labour market participation. When analysing the labor market participation trends of fathers and mothers raising young children, we found that the number of children in the family directly influences the labour market participation rate of fathers (and especially of mothers in the labor market). The participation of women in the labor market decreases with every subsequent child, while men labour market participation becomes more intensive. For example, for women with no children labour market participation rate has increased from $77.5 \%$ in 2008 to $84.7 \%$ in 2017. During the period from 2008, labour market participation of women with several young children is slightly increasing. In 2017, women's labour market participation rate stood at $86 \%$ (in comparison to $90.2 \%$ for men). The most stronger impact for women's labour market participation rate has a presence of a third child. Labour market participation rate of women with three children was only $63.4 \%$ in 2017.

One of the explanations on gender inequalities on the labour market, can be transition to parenthood (which in particularly negativelly affects women), length of the parental leave to be taken by parents, lack of affordable childcare facilities for the children until one year old, lack of reconciliation measures and flexible working time arrangements. Formally, the availability of flexible working time arrangements has increased with the entering into force of the new Labour Code (2017). It introduces new types of employment agreements and has brought flexibility to labour relations whilst individual arrangements can be requested (e.g. flexible work schedule, individual working regime, overtime, and etc.). Generally, in Lithuania, and in other Central and Eastern European countries, parents (mostly women), generally take long leaves. According to the existing literature, prolonged leave taken by mothers negatively affects their labour market participation (Hegewisch, Gornick, 2011), weakens labour market position (Thevenon, Solaz, 2013; Orloff, 2009) and also possible an upward occupational moves (Evertsson, Duvander, 2011). It would be very important to create more family friendly conditions for parents for reconciliation of paid employment and parenthood, to encourage shared parental leave among mothers and fathers.

National leave policies are continuously evolving because of changing governments, political coalitions and economic pressures (Thevenon, Solaz, 2013). Gornick and Meyers (2004) define the dual earner/dual career family as a family where both men and women participate equally in paid work and caregiving. Women's participation in paid employment increased in most Western societies, however 
family-related responsibilities mostly carried by women. According Karu, while women have entered the traditionally masculine world of employment, men have not made a similar entrance to the traditionally feminine world of family and care (2011). The dual-earner / dual-career model refers to a social and economic arrangement in which men and women engage symmetrically in both paid work (in the labour market) and unpaid work in home. Korpi (2000) identified three types of gender and family policy models: general family support, market oriented policies and dual earner support. Countries that had developed dual earner support, generally held welfare and family with more egalitarian views on gender roles; these countries have developed family and welfare systems that support female labour market participation and redistribution of care work. Lithuania, as well as many other post-communist countries, still lacks more dual-earner / career related family policy measures. The characteristics of parental leave in Lithuania are similar to most post-communist countries, especially in the long duration of parental leave (Aidukaite, 2006; O'Brien, Moss, 2010 etc.). The shift from dual-earner to dual earner-carer model has slowly appeared in European countries. Sweden, as an example, is known as a dual earner-carer family policy model already since the 1970s (Ferrarini, Duvander, 2013). The dual-earner / dual carer model implies that not only state support both parents (usually mothers') employment through various welfare provisions, but also encourages fathers' participation in childcare (Saraceno, Keck, 2011). Other Nordic countries are considered as some best examples, where the dual earner/dual career model was introduced in the second half of the 20th century.

A report of European Opinion Research Group (2004) on men's attitudes towards parental leave in $15 \mathrm{EU}$ countries showed systematic country differences. Respondents indicated that they had not sufficient information about parental leave. Among the reasons for taking parental leave, respondents had mentioned 1) effect on their career; 2) the stereotype that parental leave is more for women;

3) fear of having to do the housework, etc. There are also disparities in leave policy preferences by educational level. Higher educated women are more likely to support men's use of parental leave (European Opinion Research Group, 2004, p. 19).

\section{Country Context and Paid Parental Leave Schemes in Lithuania}

In most industrialized countries, paid leave policies (e.g. maternity, paternity and parental leaves) are key family measures. Paid parental leave systems in the European Union shows differences in how each country regulates these policies. There are significant differences in the legal regulations for paid parental leave, the 
entitlement of leave, duration etc. Paid parental leave differs not only in terms of duration, regulation, at the level of compensation for lost income due to incapacity for work, but also in other aspects. Parental leave contributes to women's economic independence and gender equality, however, parental leave as entitlement related to employment, excludes many people (for example students, workers with shorter periods of employment etc.). The basic idea in most countries is the same, i.e. the aim of ensuring the workplace, and securing an income for the employee while raising young children. In addition, there are considerable differences between countries in terms of achieving family-friendly policies: promoting labour market participation of mothers, increasing men's participation in parental leave, gender equality, childbirth, protecting the health of pregnant women and mothers who give birth; conditions for reconciling work and family roles.

From a historical point of view, for the first-time women in Lithuania gain a right to maternity leave in 1917 (at that time Lithuania was still a part of Russian empire) (Maslauskaite, Stankuniene, Baublyte, 2013). Since 1959, the leave for mothers has lasted six months. Paid parental leave in Lithuania reached one year in 1982 and mothers had a right to one-year leave with compensation equal to the minimum wage. By 1989, the leave was granted until the child was three years old. It is important to note that during the Soviet period, paid parental leave was only available for mothers. In Lithuania, as well as in other Eastern European countries, the fathers became subjects of family policies only after the collapse of the state socialism in 1990s (Karu, Pall, 2009).

Since the 1990s, as in most post-Soviet countries, in Lithuania there has been a long period of parental leave inherited from the Soviet system. In 1996 an income-related, parental leave benefit scheme was introduced in Lithuania. Major changes in paid parental leave in Lithuania occurred before becoming a member of the European Union, in 2004, when Lithuania's social policy harmonized with the EU. Currently, there are three childcare related leaves in Lithuania: maternity, paternity and parental leave (see table 1). It is important to note that major changes occurred after 2010, when as a response to an economical and financial crisis, a number of welfare retrenchment measures applied. Parental leave benefits have been reduced several times, and ceilings introduced. For comparison, in 2008 parents were entitled to 24 months of paid leave, which was reimbursed at $100 \%$ of former salary. On the impact of the crisis, 2009 the amount of paid parental leave reduced and parents were entitled to $100 \%$ of the parental leave allowance, up to one year and up to $8 \%$ - until the age of two years. In 2010, another reduction in paid parental leave took place, when parents acquired the right to $90 \%$ the amount of paid leave up to the age of one and up to $75 \%$ of the previous salary until the child is two years old. Significant changes came into effect in 2011 two options 
envisaged to parents: $100 \%$ of net earnings until the child is 12 months, or 1) $70 \%$ of net earnings until the child is 12 months and $40 \%$ of net earnings until the child is 24 months. The remaining period of leave until the child is three years of age is unpaid. Maternity, paternity and parental leave in Lithuania, as in many countries, is paid based on labour market participation and length of previous work record. The paid parental leave system 2011-2018 in a more detail presented in Table 1 (see Table 1 for the more details).

Table 1. Maternity, paternity and parental leave schemes in Lithuania 2011-2018

\begin{tabular}{|c|c|c|c|}
\hline & Duration & Payment / ceiling & Eligibility \\
\hline $\begin{array}{l}\text { Maternity } \\
\text { leave }\end{array}$ & $\begin{array}{l}\text { Eighteen }(18) \text { weeks } \\
\text { (126 calendar days; } \\
70 \text { calendar days } \\
\text { before childbirth and } \\
56 \text { calendar days } \\
\text { afterwards) }\end{array}$ & $\begin{array}{l}100 \% \text { of previous net } \\
\text { earnings (calculated } \\
\text { based on the earnings } \\
\text { in the last } 12 \text { months) }\end{array}$ & $\begin{array}{l}\text { All employed mothers } \\
\text { who have paid at least } 12 \\
\text { months of social insurance } \\
\text { contributions during the } \\
\text { last } 24 \text { months are eligible } \\
\text { for Maternity leave. Self- } \\
\text { employed women qualify } \\
\text { for maternity benefit on } \\
\text { the same conditions as } \\
\text { employees }\end{array}$ \\
\hline $\begin{array}{l}\text { Paternity } \\
\text { leave }\end{array}$ & $\begin{array}{l}\text { One month ( } 28 \\
\text { calendar days) } \\
\text { within the three } \\
\text { months immediately } \\
\text { following childbirth }\end{array}$ & $\begin{array}{l}100 \% \text { per cent of } \\
\text { previous net earnings }\end{array}$ & $\begin{array}{l}\text { Fathers who have at least } 12 \\
\text { months of social insurance } \\
\text { during the last } 24 \text { months }\end{array}$ \\
\hline $\begin{array}{l}\text { Parental } \\
\text { leave }\end{array}$ & $\begin{array}{l}\text { Until the child is } \\
\text { three years of age. } \\
\text { Leave is a family } \\
\text { entitlement and } \\
\text { shared between } \\
\text { parents }\end{array}$ & $\begin{array}{l}\text { Parents can choose } \\
\text { between two options: } \\
\text { 1) } 100 \% \text { per cent of } \\
\text { net earnings until the } \\
\text { child is } 12 \text { months; } 2 \text { ) } \\
70 \% \text { of net earnings } \\
\text { until the child is } 12 \\
\text { months, and } 40 \% \text { of } \\
\text { net earnings until the } \\
\text { child is } 24 \text { months. } \\
\text { The remaining period } \\
\text { of leave until the child } \\
\text { is three years of age is } \\
\text { unpaid }\end{array}$ & $\begin{array}{l}\text { Parents are eligible for } \\
\text { parental benefit if they have } \\
\text { paid social insurance taxes } \\
\text { at least for } 12 \text { months during } \\
\text { the last } 24 \text { months, as social } \\
\text { insurance is compulsory for } \\
\text { all workers self-employed } \\
\text { workers are eligible }\end{array}$ \\
\hline
\end{tabular}

Sources: Compiled by the authors according to the information of the State Social Insurance Fund Board (SODRA) 
Since 2019 a new tax reform was introduced and paid maternity and paternity leave benefit equals $77.58 \%$ of previous net earnings (calculated based on the earnings in the last 12 months). When it comes to parental leave benefits, parents can choose between two options: $77.58 \%$ net earnings until the child is 12 months or $54.31 \%$ of net earnings until the child is 12 months and $31.03 \%$ of net earnings until the child is 24 months.

\section{Paid Parental Leave Choices among Parents in Lithuania}

The administrative data of SODRA (The State Social Insurance Fund Board) provides information of all maternity, paternity and parental leave recipients in Lithuania. The sample of this study - total population of SODRA benefit recipients (approximately 45000 persons a year) who took paid maternity, paternity, parental leave from 2011 to 2018. The data includes information about the type of benefit (maternity, paternity, parental leave), municipality of the recipients, gender and age group of the recipients. The data also provides information about parents' choices, e.g. absolute numbers of maternity, paternity and parental leave recipients who chose to receive $100 \%$ of the benefit for one year, or 70 and $40 \%$ for two years (by gender and month). The period from 2011 to 2018 has been chosen for further analysis, because in 2011 a new regulation, allowing parents to choose between two options, was introduced.

Legally, both parents are eligible to take parental leave at equal basis, but most often mothers take parental leave in Lithuania. Men in Lithuania are not sufficiently encouraged to get involved in childcare. The administrative data of SODRA (The State Social Insurance Fund Board) had indicated that about two-thirds of women and one-third of men took parental leave in 2018. However, it should be noted that the number of fathers taking parental leave second year is constantly increasing (see figure 1 for more details). The share of fathers that are taking parental leave has increased three times since 2009, 3.3 thousands of fathers took paid parental leave in Lithuania in 2009, whilst 10.3 thousand of fathers in 2018. The numbers are presented in thousands of persons, total amount of parental leave take-ups, meaning first and second year.

Parental Leave Recipients Choices by Gender. The administrative data showed, that the second option, e.g. $70 \%$ of net earnings until the child is 12 months old and a $40 \%$ of net earnings until the child is 24 months old is more popular option among the recipients of the benefit (see figure 2), than an option to receive $100 \%$ of net earnings until the child is 12 months old. This can be interpreted that women who prefer shorter leaves and choose to receive $100 \%$ of net earnings are more 


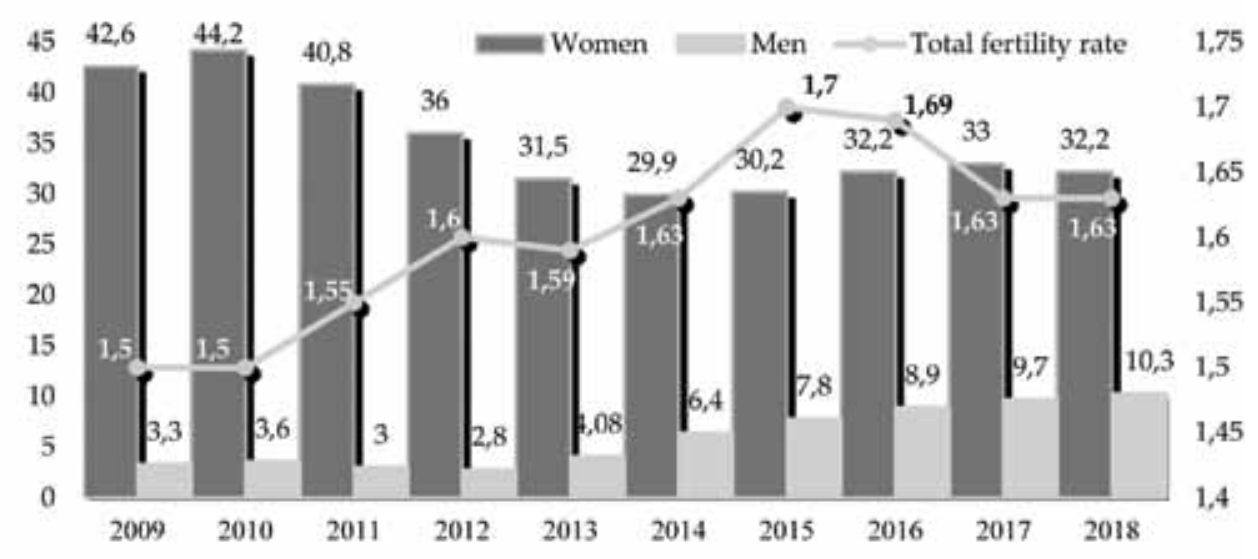

Figure 1. The total number of parental leave benefits recipients by gender and total fertility rate, 2009-2018

Sources: SODRA (State Social Insurance Fund Board) and Eurostat (tps00199)

likely to be work / career oriented or seeking possibility for upward occupational moves and long leaves might be a deal breaker. However, the fact that the majority of leave take-ups are mostly two years (70/40) shows that there aren't enough possibilities for shorter leaves, childcare facilities, arrangements between partners etc., also that parents (mostly women) still at some point, prefer longer leaves.

The administrative data indicated that the paid parental leave recipients by gender in the first year (100\% of previous income), has considerably stayed the same throughout the years. Women are taking most part of the leave accordingly from $93.3 \% 2012$ to $95.3 \% 2018$, comparing first year of parental leave for men it has decreased from about $6.7 \%$ in 2012 , to $4.7 \%$ in 2018 . This means that the number of fathers taking parental leave in the first year is still especially low, and women take the double burden for reconciling work and family life.

The administrative data showed that the share of fathers taking parental leave second year has been constantly increasing since 2011, e.g. from about $11.4 \%$ in 2011 , to $39.5 \%$ in 2018 , and for women (second year) decreasing, accordingly from $88.6 \%$ to $60.5 \%$. This option is particularly popular among fathers, because the benefit (second year) is not reduced and fathers can work whilst receiving the benefit. Although this means that some fathers are working while receiving the benefit, and the mothers are spending actual time with their children. Families choose this for mostly economical calculations and reasons. It is more useful to use father's income the second year, because the benefit is $40 \%$ of net earnings, and 


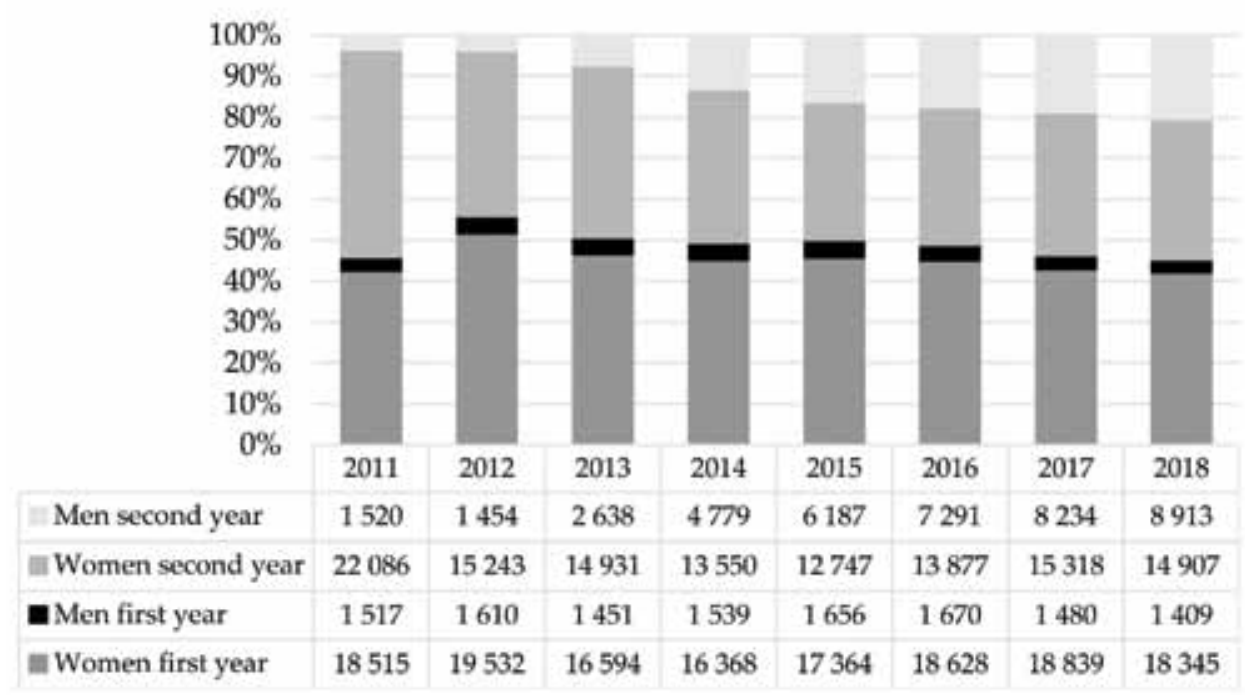

Figure 2. Parental leave benefit recipients by gender 2011-2018

Sources: Own calculations based on the State Social Insurance Fund Board (SODRA) data: open.sodra.lt file pasalpos.xlsx

while in most of the cases fathers usually earn more, families choose this structure as more beneficial. However, there is a lack of more information on how much fathers are actually spending time with their children second year while receiving the benefit, and how many of them are working. It can be said this is a loophole in the system. The number of recipients of parental leave benefit had changed significantly since 2011. Major changes have occurred in 2014 (for more information see figure 2). It can be explained by the increasing birth rate, which changed from 1.59 in 2013 to 1.7 in 2015 . These changes also can partly be explained by the implementation of different projects, for example "Complex Services for Families" project funded by ESF programme according to 2014- EU funds investment action programme 8 priority "Increasing Social Inclusion and Combating Poverty" and aimed at promotion of positive fatherhood for parents raising 1-3 years old children, family consulting and services for families. The numbers in the figure 2 (table part) below show the actual number of recipients each year. The figure above the table presents these numbers in percentages.

One of the explanations of parent's paid parental leave choices can be considerable differences of the maternity, paternity and paternity paid leave benefits amounts by gender. This clearly reflects gender pay gap among women and men that was 15.2 in 2017. Out of the administrative data of SODRA (State Social 
Insurance Fund Board), we can observe that an average amount of paternity (one month of leave possible only for fathers) benefit depending on municipality in Lithuania ranges from 690 to 1086 Euro per month. In comparison for maternity benefits they on average range from 616 to 880 Euro per month. Paid parental leave benefits range from 352 to 563 Euro per month depending on municipality. Considerable differences can be observed between urban and rural municipalities. The amount of all types of benefits are higher in urban municipalities. This can be explained by considerable regional differences.

The number of recipients of maternity and paternity benefits has not changed significantly since 2011 and remains quite stable, i.e. the number of men who have chosen to take paternity benefits and take one-month paternity leave as regulated by law (one month ( 28 calendar days) within three months immediately following childbirth) has not shifted over 1500 beneficiaries since 2011. The number of women receiving maternity benefit, i.e. (eighteen (18) weeks (126 calendar days; 70 calendar days before child birth and 56 calendar days afterwards), declined slightly since 2011 but has remained relatively constant since 2012 (see figure 3).

The number maternity and paternity benefits recipients has not changed significantly since 2011 and remains quite stable, i.e. the number of men who have chosen to take paternity benefits and take one month paternity leave as regulated by law (one month ( 28 calendar days) within three months immediately following childbirth) has not shifted over 1500 beneficiaries since 2011. The number of women receiving maternity benefit, i.e. (eighteen (18) weeks (126 calendar days; 70 calendar days before child birth and 56 calendar days afterwards), declined slightly since 2011 but has remained relatively constant since 2012 (see figure 3).

Analysing the dynamics of the total numbers of parental leave recipients by gender, we can observe a clear trend that women are much more likely to take up parental leave. However, at the end of 2013, the number of fathers taking up parental leave started to increase and the gap between mothers and fathers is slowly decreasing. While comparing the beginning of 2011 where the gap between mothers and fathers taking leave was around 40000 recipients (see figure 4). This increase of fathers taking paid parental leave since 2013, can be interpreted as a positive outcome of slightly changing norms about family and gender roles, parenthood, gender norms and life norms as a whole. Younger generations of fathers decide to take parental leave more often. However, as addressed before this could also be a financial count of families who decide to choose this structure as more beneficial and efficient.

The number of women parental leave benefits recipients between aged 25 to 30 years are significantly decreasing, while the age group of women who are taking parental aged 30 to 35 is increasing. Major changes had occurred 5 years ago. The 


\section{PAID LEAVE POLICIES AND PARENTAL LEAVE CHOICES IN LITHUANIA}

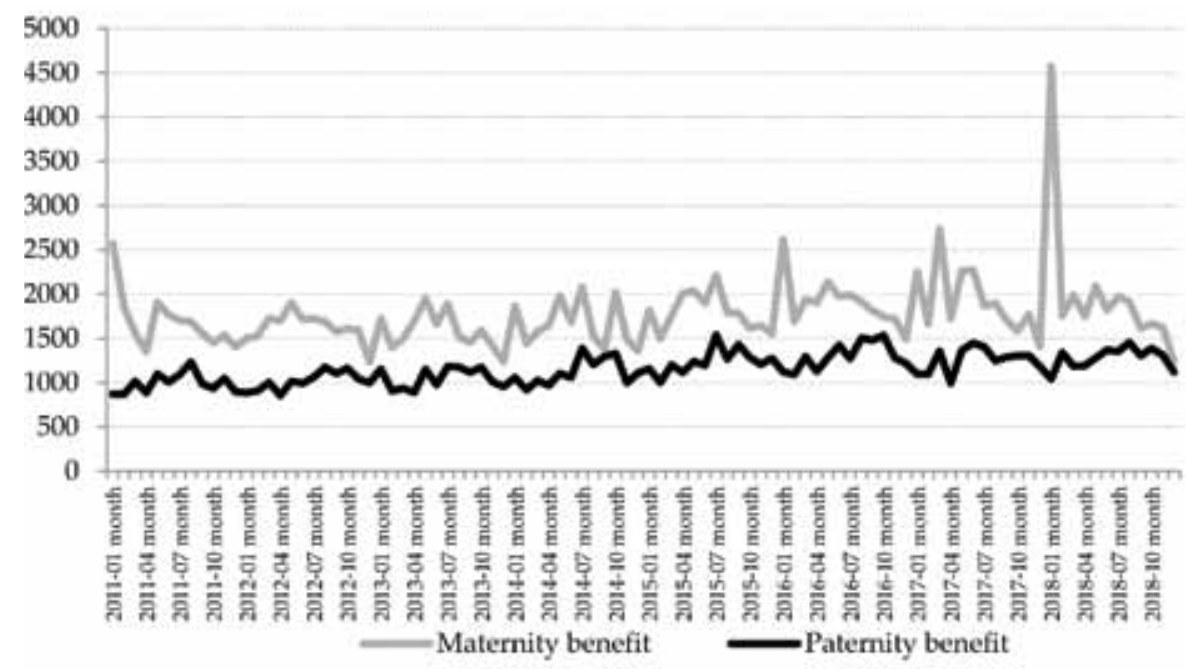

Figure 3. Changes in the number of the recipients of maternity and paternity benefits 2011-2018

Sources: State Social Insurance Fund Board (SODRA) data: open.sodra.lt file pasalpos.xlsx

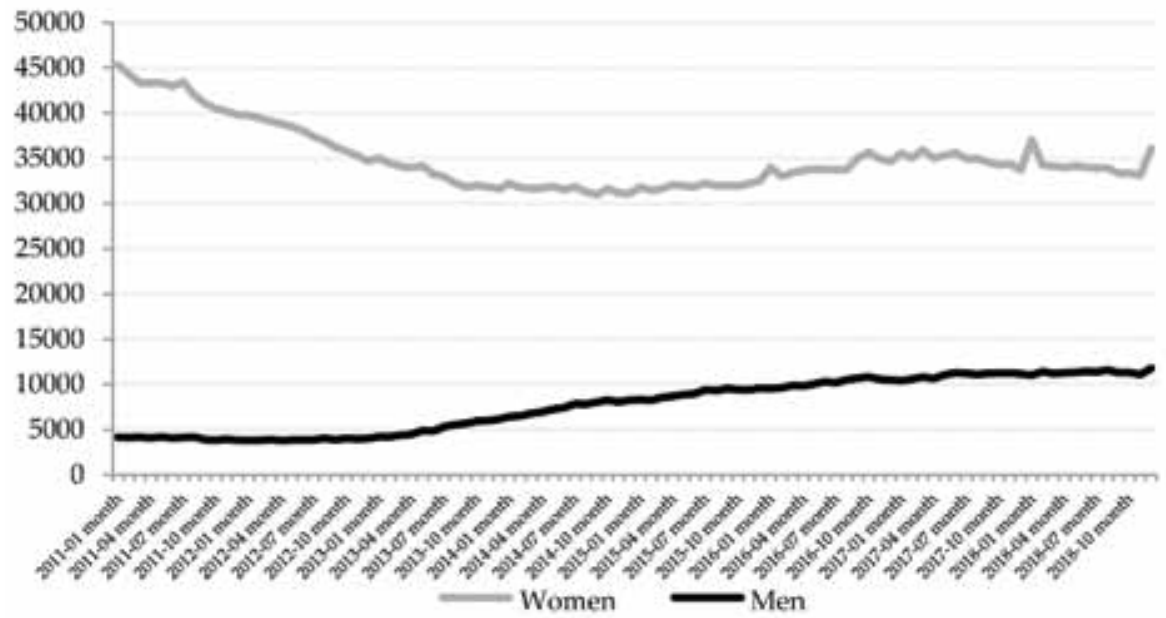

Figure 4. Parental leave benefits dynamics by gender, 2011-2018

Sources: State Social Insurance Fund Board (SODRA): open.sodra.lt file pasalpos.xlsx 
number of women aged 35-40 that are taking parental leave increases every year. Unlike women, the age of men has increased even more during the last 5 years. The number of fathers that are taking parental leave aged 30-35 had increased significantly; men reached 35-40 has also increased over the last two years and outperformed 25-30 age groups. In addition, the age group of 25-30 for both women and men that are taking parental leave has decreased significantly during the past few years. From the statistical data is evident that women postpone childbirth of the first child. Mean age of women at first childbirth from 2010 to 2017 has increased in Lithuania from 26.4 to 27.5 years.

\section{Discussion of results}

One of the priorities of the State Family Policy Concept (2008) is creation of family friendly environment, however it is limited only to a creation of conditions for the families to perform the procreative function, development of complex services for families, support for educational and social programmes and development of a positive public attitude towards the family in the society. However, issues such as the lack of flexible forms of employment, lack of childcare facilities are not emphasized. This study concerns an important aspect of parental leave policies in Lithuania - preferences of paid parental leave by recipients of the benefits. An analysis of scientific literature, strategic and legal documents, SODRA (State Social Insurance Fund Board) data, allows to conclude that the paid parental leave system in Lithuania mainly acts as a social protection system, compensating loss of income from paid employment for parent's. Generally, the paid parental system in Lithuania does not create equal preconditions for both parents' labour market participation and involvement in childcare. Also, the existing parental leave benefits system does not encourage fathers to take childcare responsibilities.

Legally Lithuanian parental leave model creates equal preconditions for fathers to contribute to parental leave, however, their contributions remain low, but on an increasing trend. Despite the fact that fathers can participate in parental leave equally with mothers, the largest part of the parental leave in Lithuania is still taken by mothers. The share of fathers that are taking parental leave is increasing constantly and in 2018 was approximately $1 / 3$ of all recipients. Using the long and generous parental leave, mothers provide familiased care for the first years after childbirth. In our study we came to very similar findings as Šarlauskas and Telešienė (2014). We also found that the second option is much more popular among parents, e.g. first year $-70 \%$ of the previous income and second year $-40 \%$ of the previous income. Considerably larger part of the fathers are receiving benefits during the 
second year and continuing to work whilst benefit is not reduced. It indicates a model of gender-based familialism, where women - due to childcare leave the paid labor market for a longer period (two years), receiving $70 \%$ of their previous income first year, and $40 \%$ of previous income second year.

Maternity, paternity and parental leave can have (should have?) a positive impact on women's employment, but long paid parental leave tends to have a negative impact on women's / mothers' salaries and career prospects. We can clearly observe this by an example of Lithuania that long parental leaves has a negative impact on women's employment. This can be addressed as a circular issue - i.e. women earn less, so choose to take longer leaves, which according to other studies, will decrease their earnings from employment. Allowing parents to choose parental leave as they prefer usually leads to women taking up the leave. Some countries have introduced policies that aim at changing gender stereotypes, for example father's quota in the parental leaves scheme. Fathers quota or other significant mandatory obligations would benefit to a more equal labour market participation opportunity for women and men. Working hours as part time or flexible working time arrangements are quite unpopular in Lithuania. This means that on this day, when it comes to having children, women in Lithuania experience double burden - taking long leaves - accepting long exits from labour market and possible job loss; taking short leaves - lack of childcare facilities or possible flexible day care centres, also possible negative attitude from family members.

\section{References}

Aidukaite, J. (2006). Reforming Family Policy in the Baltic States: The Views of the Elites. Communist and PostCommunist Studies, Vol. 39 (1), p. 1-23.

Almqvist, A. L., Duvander, A. Z. (2014). Changes in Gender Equality? Swedish Fathers' Parental Leave, Division of Childcare and Housework. Journal of Family Studies, Vol. 20 (1), p. 19-27.

Buunk, B. P., Kluwer, E. S., Schuurman, M. K., Siero, F. W. (2006). The Division of Labor Among Egalitarian and Traditional Women: Differences in Discontent, Social Comparison, and False Consensus. Journal of marriage and the family, Vol. 49 (1), p. 29-40. Doi: 10.2307/352667

Braziene, R. (2020). 'Lithuania country note'. In A. Koslowski, S. Blum, I. Dobrotić, G. Kaufmann, P. Moss (eds.). International Review of Leave Policies and Research 2020. Available at: http://www.leavenetwork. org/lp_and_r_reports.

Braziene, R. (2019). Lithuania country note. In A. Koslowski, S. Blum, I. Dobrotić, G. Kaufmann, P. Moss (eds.). International Review of Leave Policies and Research 2019. Available at: http://www.leavenetwork.org/lp_ and_r_reports/

Braziene, R. (2018). Lithuania country note. In P. Moss (ed.). International Review of Leave Policies and Research 2017. Available at: http://www.leavenetwork.org/lp_and_r_reports/

Braziene, R. (2017). Lithuania country note. In P. Moss (ed.). International Review of Leave Policies and Research 2016. Available at: http://www.leavenetwork.org/lp_and_r_reports/

Castles, F. C. (2003). The world turned upside down: below replacement fertility, changing preferences and family-friendly public policy in 21 OECD countries. Journal of European Social Policy, Vol. 13 (3).

Duvander, A. Z., Ellingsæter, A. L. (2016). Cash for Childcare Schemes in the Nordic Welfare States: Diverse Paths, Diverse Outcomes. European Societies, Vol. 18(1), p. 70-90. 


\section{Rūta Brazienė, Sonata Vyšniauskienė}

Duvander, A. Z., Viklund, I. (2019). How long is a parental leave and for whom? An analysis of methodological and policy dimensions of leave length and division in Sweden. Stockholm Research Reports in Demography.

Duvander, A. Z., Johansson, M. (2019). Does Fathers' Care Spill Over? Evaluating Reforms in the Swedish Parental Leave Program. Feminist Economics, Vol. 25(2), p. 67-89.

Evertsson, M., Duvander, A. Z. (2011). Parental Leave - Possibility or Trap? Does Family Leave Length Effect Swedish Women's Labour Market Opportunities? European Sociological Review, Vol. 27 (4), p. 435-450.

Esping-Andersen, G. (1999). Social Foundations of Post-industrial Economies. New York: Oxford University Press.

Ferrarini, T., Duvander, A. Z. (2010). Earner-Carer Model at the Crossroads: Reforms and Outcomes of Sweden's Family Policy in Comparative Perspective. International Journal of Health Services, Vol. 40 (3), p. 373-398

Greenstein, T. N. (1996). Husbands' Participation in Domestic Labor. Interactive Effects of Wives' and Husbands' Gender Ideologies, Vol. 58, No. 3, p. 585-595. Doi: 10.2307/353719

Gornick, J., Meyers, M. (2003). Families That Work: Policies for Reconciling Parenthood and Employment. Russell Sage Foundation. Retrieved from http://www.jstor.org/stable/10.7758/9781610442510

Hegewisch, A., Gornick, J. C. (2011). The Impact of Work-Family Policies on Women's Employment: A Review of Research from OECD Countries. Community, Work \& Family, Vol. 14(2), p. 119-138.

Hoffman, C. D., Moon, M. (1999). Women's Characteristics and Gender Role Attitudes: Support for Father Involvement with Children. The Journal of Genetic Psychology, Vol. 160, p. 4, 411-418. Doi: $10.1080 / 00221329909595554$

Inglehart, R., Norris, P. (2003). Rising Tide - Gender Equality and Cultural Change Around the World. ISBN $0-521-82203-3$

Kamerman, S., Moss, P. (eds.) (2009). The Politics of Parental Leave Policies: Children, Parenting, Gender and the Labour Market. Portland, OR: Policy Press.

Karu, M., Pall, K. (2009). Estonia: from Soviet Union to half way to the Nordic Countries. In S. B. Kamerman, P. Moss (eds.). The politics of parental leave policies: Children, parenting, gender and the labour market, p. 69-85. Bristol: The Policy Press.

Korpi, W., Ferrarini, T., Englund, S. (2013). Women's Opportunities under Different Family Policy Constellations: Gender, Class, and Inequality Tradeoffs in Western Countries Re-examined. Social Politics: International Studies in Gender, State \& Society, Vol. 20 (1), p. 1-40. Available online: https://doi.org/10.1093/sp/jxs028

Korpi, W. (2000). Faces of Inequality: Gender, Class, and Patterns of Inequalities in Different Types of Welfare States. Social Politics: International Studies in Gender, State \& Society, Vol. 7 (2), p. 127-191. Available online: https://doi.org/10.1093/sp/7.2.127

Kluwer, E. S., Heesink, A. M., Van De Vliert, E. (1997). The Marital Dynamics of Conflict over the Division of Labor. Journal of Marriage and Family, Vol. 59, No. 3, p. 635-653. Doi: 10.2307/353951.

Lammi-Taskula, J. (2007). Parental leave for fathers? Gendered conceptions and practices in families with young children in Finland. ISBN 978-951-33-2011-9.

Merla, L. (2008). Determinants, Costs, and Meanings of Belgian Stay-at-Home Fathers. An International Comparison Fathering, Vol. 6, No. 2, p. 113-132. Doi: 10.3149/fth.0602.113

Morgan, D. H. J. (1992). Discovering men. London: Routledge.

O'Brien, M., Moss, P. (2010). Fathers, Work and Family Policies in Europe. The Role of the Father in Child Development. New York: Wiley, Hoboken.

Orloff, A. S. (2009). Gendering the Comparative Analysis of Welfare States: An Unfinished Agenda. Sociological Theory, Vol. 27, p. 317-343. Doi: 10.1111/j.1467-9558.2009.01350.x

Pfau-Effinger, B. (2004). Socio-historical paths of the male breadwinner model - an explanation of cross-national differences1. The British Journal of Sociology, Vol. 55: 377-399. Doi:10.1111/j.1468-4446.2004.00025.x

Reingardienè, J., Tereškinas, A. (2006). Darbo ir šeimos gyvenimo suderinimas Lietuvoje bei lyčių lygybė: iššūkiai ir galimybès. In J. Reingardienè (sud.). (Ne)apmokamas darbas: šeimai palanki darbo aplinka ir lyčiu lygybẻ Europoje. Vilnius: Vytauto Didžiojo universitetas, Lygių galimybių plètros centras.

Ridgeway, C. L. (2011). Framed by Gender - How Gender Inequality Persists in the Modern World. ISBN 9780-19-975577-6

Saraceno, C., Keck, W. (2011). Towards an integrated approach for the analysis of gender equity in policies supporting paid work and care responsibilities. Demographic research, Vol. 25 (11), p. 371-406. Doi: 10.4054/DemRes.2011.25.11

Shelton, B. A., John, D. (1996). The Division of Household Labor. Annual Review of Sociology, Vol. 22 (1), p. 299-322. ISSN 0360-0572. Doi: 10.1146/annurev.soc.22.1.299 


\section{PAID LEAVE POLICIES AND PARENTAL LEAVE CHOICES IN LITHUANIA}

Shelton, J. D., Luschen, K. (1995). Race, Ethnicity, Gender, and Perceptions of Fairness. Journal of Family Issues, Vol. 16(3), p. 357-379. Available at: https://doi.org/10.1177/019251395016003007

Stankūnienè, V. (2001). Paramos šeimai politika: samprata ir patyrimas. Vilnius: Lietuvos filosofijos ir sociologijos institutas.

Stankūnienè, V. (2003). Šeimos revoliucija? Ǐš̌ūkiai šeimos politikai. Vilnius: Socialinių tyrimų institutas.

Šarlauskas, T., Telešienè, A. (2014). The Regulation of State Social Insurance: Structure and Choices of Beneficiaries “Public Policy and Administration”. ISSN online 2029-2872/ISSN print 1648-2603.

The Action Plan of Comprehensive Provision of Services for Families 2016-2020. Available at: https://www.e-tar. 1t/portal/lt/legalAct/7cf92540e6b511e5ba46c884bbd2b4fd

The State Family Policy Concept. (2008). Available at: https://www.lrkt.lt/en/court-acts/search/170/ta1112/ content

The Law on Equal Opportunities for Women and Men. Available at: http://www3.1rs.lt/pls/inter3/dokpaieska. showdoc_1?p_id=276095

The Law on Equal Treatment. Available at: http://www3.lrs.1t/pls/inter3/dokpaieska.showdoc_1?p_id=222522\&p_ query=\&p_tr2=

Lithuanian Labour Code. (2017). Available at: https://www.e-tar.lt/portal/lt/legalAct/ f6d686707e7011e6b969d7ae07280e89

Thevenon, O. (2011). Family Policies in OECD Countries: A Comparative Analysis. Population and Development Review, Vol. 37 (1). Available at:https://doi.org/10.1111/j.1728-4457.2011.00390.x

Thevenon, O., Solaz, A. (2013). Labour Market Effects of Parental Leave Policies in OECD Countries OECD Social, Employment and Migration. Working Papers, No. 141. ISSN: 1815199X. Available at: https://doi. org/10.1787/1815199X

Thompson, L., Walker, A. J. (1989). Gender in Families: Women and Men in Marriage, Work, and Parenthood. Journal of Marriage and Family, Vol. 51, No. 4, p. 845-871. Doi: 10.2307/353201

Valarino, I., Duvander, A. Z., Haas, L., Neyer, G. (2018). Exploring Leave Policy Preferences: A Comparison of Austria, Sweden, Switzerland, and the United States. Social Politics: International Studies in Gender, State \& Society, Vol. 25(1), p. 118-147.

Rūta Brazienè - associate professor, doctor of Social Sciences (Sociology), Department of Social Policy, Faculty of Philosophy, Vilnius University, Lithuania. E-mail: ruta.braziene@gmail.com 